I State Univeristy of Rio de Janeiro, Institute of Social and Political

Studies (Iesp/Uerj), Rio de Janeiro, RJ, Brazil

carloscr@iesp.uerj.br

Carlos Antonio Costa Ribeiro'

\title{
OCCUPATIONAL AND INCOME INTERGENERATIONAL MOBILITY IN BRAZIL BETWEEN THE 1990s AND 2000s
}

\section{INTRODUCTION}

The relationship between stratification and social mobility is central to the sociological approach to inequalities. A long tradition of sociological research on social mobility seeks to establish the relationship between inequalities in the generations of parents and children. The resources of parents are correlated to their children's chances of social mobility, which implies that the inequalities between parents are reproduced to some extent in the children's generation. In this sense, there has always been an interest in understanding how changes in levels of inequality - produced, for instance, by industrialization - can lead to changes in patterns of intergenerational mobility. Many studies of social mobility look, for example, to analyse the convergence in patterns of mobility that occur as countries become industrialized (Breen \& Jonsson 2005; Breen 2005; Ribeiro 2007). Although the majority of sociological studies have emphasized more structural changes in the occupational composition of societies, there is no reason not to study the changes to other indicators of the socioeconomic situation such as income, for instance. In this article I compare trends in occupational and income mobility in Brazil using data on education, occupation and income of parents and children between the I 960 s and the 2000 s.

During this period, there was an observable increase in income inequality between 1960 and the end of the I 980 s, indicated by the fact that the Gini index (where the closer to I, the greater the inequality) rose from 0.535 in I 960 
to 0.636 in 1989 , while in the I990s and 2000 s there was a fairly significant fall in income inequality with the Gini index lowering constantly from I 994 onward. Another form of verifying this reduction is to observe the ratio between the incomes of the wealthiest and the poorest. In I990, for example, the richest I0\% of the population had an average income 26 times higher than the poorest $40 \%$, a disparity that had fallen to I 4 times higher by 2010 . Some studies suggest that the reduction in income inequality led to a substantial increase in social mobility (Neri, 20I I). However, these studies do not analyze social mobility directly, since they merely compare income distributions at different moments in time - that is, they observe that a significant portion of the population obtained a rise in income, but they are unable to ascertain whether this increase involved the same people nor, much less, whether there was any income mobility in relation to the income of the families of origin (the parents) of the people studied. A decrease in income inequality, however, implies that material resources become less unequal between the children of the wealthiest and the poorest, which may have led to an increase in social mobility.

The reduction in income inequalities poses a number of challenges to the study of social mobility. Sociological research in Brazil has focused primarily on class mobility, defined by the aggregation of occupations with similar labour relations (Ribeiro, 2007, 20 I2; Scalon, I999; Torche \& Ribeiro, 2010; Pastore \& Silva, 2000; Pastore, I98I). As a result of the decline in income inequality, however, classes (occupational clusters) are no longer able to capture important changes in socioeconomic status, given that inequality diminished both within social classes and between them (Carvalhaes, et al., 20I4). In order to examine the reproduction of inequality over the last two decades, analyses of mobility should also turn to the study of income mobility. In Brazil, though, there is an absence of longitudinal data allowing direct measurement of parental income, meaning that alternative forms of measuring this distribution are needed. The fact that reliable data on income and occupational mobility are available from the I97os enables us to estimate the income of the parents using a relatively simple technique (Agristi \& Krueger, I992; Bjorklund \& Jantti, I997). As this technique involves using occupation to estimate the income of parents and combining different surveys, I also consider it important to analyze mobility in terms of occupational status.

In Brazil income mobility was analyzed for I 996 only and all the available studies, with one exception (Osório, 2009), have been made by economists (Pero \& Szerman, 2008; Ferreira \& Veloso, 2006; Dunn, 2004). All these works use parental occupation, a variable obtained retrospectively in surveys on occupational mobility, to estimate parental income. The works of these economists, however, do not directly explore the information on occupation and education of the parents of the respondents. Sociology contains two distinct approaches 
to the study of social mobility, both of which take into account information on the occupation of parents and children. The first approach, cited earlier, utilizes occupational clusters to construct social class variables (Ribeiro, 2007, 20I 2; Scalon, I999; Torche \& Ribeiro, 2010; Pastore \& Silva, 2000; Pastore, I98I). The other approach is formed by studies of socio-occupational status mobility (status attainment), which classify all occupations on a hierarchical scale based on socioeconomic criteria. There are also various studies focused on Brazil that adopt this perspective (Bills, Godfrey \& Haller, I985; Bills, Haller, I985; Haller, I99I). Some authors suggest that this ranking, known as a socioeconomic or occupational status index, can be interpreted as an indicator of the permanent income of individuals, i.e. the average income obtained during their lifetime (Hauser \& Logan, I992).

In this article I set out to investigate these topics, looking to attain two objectives. The first is to determine whether there were changes in the levels of income and socio-occupational mobility in the period when income inequalities fell between I996 and 2008. And the second is to compare the approaches of sociology and economics to the study of intergenerational social mobility.

As well as comparing these two approaches, I present various analyses of educational mobility. We know that the reduction in income inequality in Brazil is directly associated with the reduction in educational inequality, which means that the level of schooling attained is also central to explaining both income mobility and occupational status mobility. For this reason, I also analyze intergenerational mobility in terms of educational level attained by parents and children. Education is the main characteristic intermediating the income or occupation of parents and the income or occupation of children. My analyses break down income and occupational mobility taking educational mobility as a mediating factor.

In sum, I analyze recent trends in the social mobility of Brazilian men by examining three kinds of mobility: educational, income, and occupational status. The analyses are limited to social mobility within a narrow age range since the income of individuals varies considerably over their life time. In the case of women, the variation is even higher and the comparison would have to be made with their fathers, not their mothers. Consequently, income mobility would reflect not just intergenerational change but gender inequality too. Analyses of income mobility are extremely susceptible given that the life cycles of men and women differ markedly. For these reasons it is important to narrow the range of the analyses to men's mobility trends. In relation to intergenerational mobility of men and women, important studies exist on the topic of occupational mobility (Ribeiro, 2007; Scalon, I999). The present article thus complements recent works on trends in intergenerational class mobility (Ribeiro, 20I2), as well as other studies on diverse aspects of intergenerational mobility (Ribeiro, 2007; Scalon, I999; Torche \& Ribeiro, 2010). The following analyses 
compare the experiences of social mobility of men among two age cohorts. The oldest were born between I960 and 1969, were aged between 7 and I6 in 1976 (the year for which I estimate the father's income) and between 27 and 36 in I 996 (the year when their own income, occupation and education were measured). The youngest cohort were born between 1972 and I98I, were aged between 7 and 16 in 1988 and between 27 and 36 in 2008. While the older cohort reached their thirties in a period marked by high levels of inequality at the beginning of the I99os, the younger cohort reached this age at a moment involving a significant fall in inequality in the 2000 s.

\section{SOCIAL MOBILITY: INCOME, OCCUPATION AND EDUCATION}

Social mobility is defined by patterns and levels of association between the socioeconomic conditions of parents and those of their adult children: the higher the association, the lower the social mobility. Socioeconomic conditions are measured in different ways. Generally speaking, sociologists tend to use measures based on the occupation of parents and adult children operationalized in two forms: as a ranked index of the socioeconomic status of all occupations or as occupational clusters (combining three or more categories) defining social classes with different positions in the production structure. Economists, for their part, tend to use income-based measures, generally wage earnings or household income. This topic has been studied empirically by sociology since the I950s. It only began to be researched by economists in the I980s, though. The use of these different measures generally leads to distinct results concerning social mobility patterns and trends. In this article I compare the trends between 1996 and 2008 using two measures for the socioeconomic conditions of fathers and sons: occupational status and family income. The results obtained for each measure differ, although both reveal an increase in social mobility in the period studied.

Occupational status is a measure that ranks all occupations according to their average income and education levels. Detailed information on the occupation of people and their parents is easy to collect: virtually nobody declines to reply to questions about occupation, which is not the case when it comes to information about income. Children also have little difficulty recalling their parents' occupation when they were growing up, which likewise is not the case in relation to their income (Hauser \& Warren, I997; Hout, 2015). Furthermore, an individual's occupational status remains relatively stable throughout their life, making it a fairly reliable indicator of their socioeconomic situation. Even some economists recognize advantages to the use of occupation compared to income as a measure of socioeconomic condition (Goldberger, I989).

There exists a long sociological tradition of studies on social mobility based on occupational status measures, beginning with the work of Blau and Duncan (1967), and known still today as status attainment studies. Various 
works pursue this approach to study social mobility in Brazil (Bills, Godfrey \& Haller, I985; Bills \& Haller, I985; Haller, I99I). The main theme of these studies is the relation between economic development and changes in the mobility of occupational status. In absolute terms, there was a significant increase in occupational status mobility (measured in terms of the average of this indicator): in 1973 the occupational status average of adult men ( 25 to 64 years old) was 30.6; in I982, 31.9; in I996, 33.2; and in 2008, 36.0. ${ }^{\mathrm{I}}$ For the two cohorts analyzed in this article, the averages were 34.2 in 1996 , and 36.5 in 2008. The relative mobility of status is measured by linear regressions of the occupational status of the child on that of the parent - the method I use in this article - which estimates a regression coefficient that expresses the intergenerational persistence of occupational status. The diverse studies adopting this approach indicate that this persistence is fairly high in Brazil. In this article, the coefficients are 0.45 in 1996 and 0.42 in 2008. For adult men (aged 25 to 64 years) this coefficient was 0.556 in $1973,0.529$ in $1982,0.496$ in 1996 and 0.416 in $2008 .^{2}$ In other words, there was an increase in occupational status mobility in Brazil between the ig7os and the 2000 .

From their outset, sociological studies of occupational status mobility have used diverse variables mediating the status of parents and children. This type of approach began to be adopted only a few years ago in studies by economists. Although sociologists have used structural equation models to analyze a variety of mediators, the education attained by children remains the primary mechanism of social mobility. Education is both a factor in the reproduction of inequalities, as Bourdieu and Passeron (1977) hypothesize in their theory of reproduction, and a factor in overcoming inequalities, as proposed by Becker (I964) in his theory of human capital, and Blau and Duncan (1967) suggested in their book on occupational structure in the United States. The sociological research showed that for people whose parents have a high occupational status, education functions as a means of guaranteeing high status, but for those whose parents have low status, education is the principal mechanism of upward mobility (Hout \& Diprete, 2006). In general, education lessens the direct effect of the parent's status on the child's. In this article, I present the same kind of analysis, but I call the direct effect 'pure occupational inheritance' (discounting the effect of education) and the indirect effect 'mediated occupational inheritance' (mediated by the child's education).

Although sociology has been pioneering in the studies of social mobility, economists have also made important contributions. Instead of using occupation as an indicator of socioeconomic conditions, they use income. Furthermore, there are important theoretical works in economics on intergenerational mobility that should be more closely studied by sociologists - for a simplified version of the model proposed by Becker and Tomes (I986), see the article by Solon (2004). It is also true, however, that economists should pay more 
attention to sociological studies, as the economist Goldberger (I989) points out. Using income instead of occupation necessitates taking a number of specific methodological precautions.

Studies of income mobility evaluate intergenerational association by means of the linear regression of the log of the adult children's income on the log of parental income or the percent distribution of these incomes. The logarithm derives from the fact that income distributions are not linear. Using the formulation with the two logs (parental and adult child incomes), the regression coefficient is defined as the 'elasticity' that captures the mean percentage change in the children's income associated with a $\mathrm{s} \%$ change in the parents' income. For example, a coefficient of 0.4 indicates that a $10 \%$ difference in income of the parents is associated with an average difference of $4 \%$ in the children's income. I adopt this approach in the present article, but it is also worth recalling the existence of a different formulation that uses percentages and has the advantage of being able to include cases with zero income. Although the elasticity (regression coefficient) is a measure of the relative, rather than absolute, mobility, it may be influenced by changes to the levels of inequality between generations, which occurred in Brazil, where there was a reduction in income inequalities. For this reason, the correlation coefficient may also be used since it adjusts elasticity using the ratio between the standard deviations of the incomes of parents and children $\left(\sigma_{\rho \varepsilon} / \sigma_{\rho \varepsilon}\right)$. Hence the correlation is not mechanically affected by the change in inequality between generations, and its values vary between $o$ and $\mathrm{I}$, with $\mathrm{o}$ indicating independence between origin and destination, and I indicating a perfect association. In this article I employ this approach to study income mobility. It is important to remember that most studies analyze mobility in terms of wage earnings, but there are also important studies that use family income or income from all sources (Torche, 20I5), which would be a more complete measure since it takes into account other incomes coming, for example, from spouses and mothers.

In this article I use data on family income and take a number of precautions to avoid methodological problems familiar to studies of income mobility. The theories in this area (Becker \& Tomes, I986) suggest that analyses should set out from the concept of 'permanent income,' i.e. the permanent expectations for intergenerational transferences and consumption. The data used in most empirical studies, however, are on transitory income at the moment of the person's life when it is measured (month or year). This limitation entails the need to adopt for a series of precautions when undertaking empirical analyses (Torche, 20I5). For example, the moment of the life cycle when the income of the parents and children was measured should be taken into account. It is precisely for this reason that the analyses presented by myself in this article are limited to men and to a narrow age cohorts. 
Although occupation and income can be seen as indicators of something more general than socioeconomic conditions, the results of studies on occupational mobility (socioeconomic status or class) and income mobility (individual or family) tend to diverge. For example: (I) when compared to other developed countries, the United States shows considerable occupational mobility and little income mobility (Corack, 2004); (2) while income mobility is strongly associated with economic inequality, occupational mobility is only modestly associated (Corack, 2004; Erickson \& Goldthorpe, I993). The patterns observed in Brazil are also different. International comparisons indicate that in terms of class mobility (social fluidity), Brazil is not among the countries with least mobility, but in the middle of the distribution, close, for instance, to Hungary (Ribeiro, 2007). In terms of income mobility, though, Brazil is among the countries with least mobility, since the income elasticities were observed at around 0.66 and 0.73 in 1996 (Pero \& Szerman, 2008; Ferreira \& Veloso, 2006; Dunn, 2004). Some studies on class mobility trends indicate a considerable increase in social fluidity between the I970s and the 2000s (Ribeiro, 2012; Torche \& Ribeiro, 2010). There are no studies on historical trends in income mobility due primarily to the absence of data. One of the main results of the analyses that I present below is precisely what they reveal about the increase in income mobility in Brazil.

As well as presenting income and occupational mobility trends, I analyze the mediating role of education and educational mobility. In an earlier study, Ribeiro (2OI2) shows that in terms of class mobility there was little equalization of access to education (the association between the parents' class and the education of their children), but there was a reduction in the returns on education (the association between the child's education and the class of destination). Around $40 \%$ of the increase in class mobility is attributable to the role performed by the education attained by the children (Ribeiro, 2012), while around $50 \%$ of income mobility is due to factors linked to the children's education (Bourguignon, Ferreira \& Menéndez, 2007). In the following analyses I show the trends since 1996, the first date for which data on income mobility is available.

\section{DATA AND MEASUREMENTS}

As I mentioned in the introduction, I use data for two age cohorts observed during childhood in the PNAD I976 (National Household Sample Survey) and PNAD I988, and during adulthood in the PNAD I996 and PDSD 2008 (Social Dimensions of Inequalities Survey). All these surveys are probabilistic samples of Brazilian households. ${ }^{3}$ The older cohort was aged between 27 and 36 in 1996 and between 7 and 16 in 1976, while the younger cohort was aged between 27 and 36 in 2008 and between 7 and 16 in I988. The PNADs for 1976 and I 988 were used to estimate the 'log of income from all sources' of the fathers with male children aged between 7 and 16 at the time of the survey. The PNAD I996 and PDSD 2008 were used to obtain the 'log of income from all sources' of the sons. 
The latter two surveys contain retrospective information on the occupation and education of the respondents' parents which is used both to calculate the income of the fathers - the only procedure permitting analysis of the income mobility with the data available for Brazil - and to analyze educational and occupational mobility. I chose the age range of sons between 27 and 36 because this increases the certainty that they were still living with their parents twenty years earlier when they were aged between 7 and 16 .

To determine the income of the fathers, a method developed by Bjorklund \& Jantti (I997) and Agristi \& Krueger (I992) was used called the two samples instrumental variable (TSIV). This involved estimating the 'log of income of the fathers' in two stages. In the first I estimated a linear regression model (OLS) in which the dependent variable comprises the 'log of income from all sources' of adult men (generally defined as household heads) who had male children aged between 7 and I 6 years in 1976 and I988. The independent variables are the 'years of education' and 'occupational status' (ISEI) of these adult men. 'Years of education' was measured by completed years of education and 'occupational status of the household head' was obtained from the International Socioeconomic Index (ISEI) developed by Gazeboom, Treiman \& De Graff (I 993). This index ranks occupations according to corresponding average values for income and education, and is normally interpreted in the sociological literature as a proxy for 'permanent income,' i.e. income discounting fluctuations over the person's life cycle. The index attributes a scale of values ranging from i6 to 9o. The ISEI is also used directly to analyze the occupational mobility of the two age cohorts with the objective of comparing the economic and sociological approaches to studies of social mobility. The second stage of the TSIV method involves estimating the income from the 1996 and 2008 samples using the estimated parameters for the effect of 'years of education' and 'occupational status' on the linear regressions (OLS) taking the 'log of income' as a dependent variable in the samples of fathers (adult men with male children aged between 7 and I6) using the PNADs for I976 and I988. Table I presents the models used to estimate the 'log of paternal income' in the samples of fathers in I976 and I 988. 


\begin{tabular}{|c|c|c|}
\hline \multicolumn{3}{|l|}{ Sample of Fathers In: } \\
\hline & I976 & I988 \\
\hline Paternal education & O.I3I & 0.106 \\
\hline s.d & 0.002 & 0.002 \\
\hline Paternal occupation & 0.017 & 0.025 \\
\hline s.d & 0.000 & 0.001 \\
\hline Intercept & 4.257 & 5.158 \\
\hline s.d & 0.009 & O.0I4 \\
\hline $\mathrm{R} 2$ & 0.409 & 0.482 \\
\hline $\mathrm{N}$ & 40913 & 25252 \\
\hline
\end{tabular}

Table I

Regression analysis used to estimate the log of paternal

income in 1976 and I988 (PNADs)

After estimating income in the samples of the fathers (I976 and 1988), this income was calculated for the sample of sons using the instrumental variables 'years of education' and 'occupational status' (ISEI) obtained from retrospective responses in which adult children (PNAD I996 and PDSD 2008) indicated the occupation and years of education of their fathers at the time when they, the sons, were I5 years old.4 In the PNAD I996, for example, we have information on the education and occupation of the respondents' fathers but not on their income. Using the linear regression presented in Table I, we know that: (I) in 1976 the regression coefficient estimating the effect of the 'completed years of education' on the 'log of income' of men who had sons aged between 7 and I 6 was O.I3I; (2) the coefficient for the effect of 'occupational status' (ISEI) was 0.0I7; and (3) the intercept was 4.257 (all statistically significant). These three coefficients estimated in the sample of the fathers in 1976 were used to estimate paternal income in the 1996 sample using the retrospective information on the 'years of education' and 'occupational status' of the fathers of respondents aged between 27 and 36. I therefore used the following formula to obtain the income of their fathers in 1996:

In (father's estimated income)

$=4.257+$ O.I3I (father's years of education, retrospective information)

+ 0.017 (father's occupational status, retrospective information)

To obtain the paternal income for 2008 , I used the linear regression presented in Table I for the sample of fathers in I988. This method is an indirect form (though the only one possible with the data available for Brazil) of obtaining paternal income, essential to our analysis of intergenerational income mo- 
bility. Since I obtained variables for the "log of income of the fathers" in the samples for the two age cohorts in 1996 and 2008, I have all the variables necessary to analyze the intergenerational mobilities of income, education and occupation. To analyze intergenerational income mobility, a deflator also had to be used to adjust incomes to a value relative to September 2008. All the variables for 'income from all sources' used are deflated, therefore, to the corresponding value in 2008. Table 2 below shows the descriptive statistics for the different variables in each sample of fathers and sons.

The statistics relating to the variables 'years of education,' 'occupational status' and 'log of parental income' (estimated in 1996 and 2008, and observed in 1976 and 1988) in the samples of the fathers and sons do not differ greatly. For the younger cohort ( 27 to 36 years old in 2008) observed in the PDSD 2008, for example, the means for paternal occupational status, education and log of income (estimated) are 4.4 years of education, 33. I points on the ISEI scale, and 6.435 on log of income, respectively. In the data on fathers (obtained from PNAD I 988 ) the equivalent means are: 3.8 years of study, 30.7 points on the ISEI scale and 6.336 on the log of income. For the older cohort aged between 27 and 36 in I996, comparing the same information for fathers in 1976 and 1996 also reveals no significant difference between the two surveys (PNAD I976 and I996). Taking into account that the PDSD is an independent survey, not compiled by the Brazilian Institute of Geography and Statistics (IBGE), 5 I also compare the income in the PDSD 2008 with the income in PNAD 2008 at the end of Table 2. The average income for men aged between 27 and 36 is R $\$$ I,03I in the PDSD (s.d.=I3I0.9) and $\mathrm{R} \$ \mathrm{I}, 065$ in the PNAD (s.d.=I433.4). This comparison indicates that income in the PDSD was accurately estimated when we take as a basis for comparison the income declared in the PNAD, a survey more widely known and used than the former.

Before turning to the analyses in the next section, it is important to emphasize that I conducted various tests to estimate the 'log of paternal income' in the two samples. A central concern was to check whether the association between 'paternal occupation' and 'paternal education,' on one hand, and 'log of income from all sources,' on the other, was really linear. I employed various tests to check the robustness of these associations and concluded that they really are linear, irrespective both of the specifications of the variables for occupation and education and of the inclusion or exclusion of the variable for age of fathers and/or sons in the regressions. 


\begin{tabular}{|c|c|c|c|c|c|c|c|}
\hline \multicolumn{8}{|c|}{ Comparing PNAD I 988 with PDSD 2008} \\
\hline & & \multicolumn{3}{|c|}{ Sample of Sons PDSD 2008} & \multicolumn{3}{|c|}{ Sample of Fathers PNAD 1988} \\
\hline & & $\mathrm{N}$ & Mean & s.d. & $\mathrm{N}$ & Mean & s.d. \\
\hline \multirow[t]{5}{*}{ Fathers } & paternal age & & & & 25252 & 42.5 & 8.6 \\
\hline & years of education & 853 & 4.4 & 4.2 & 25252 & 3.8 & 4 \\
\hline & $\begin{array}{l}\text { paternal occupation } \\
\text { status }\end{array}$ & 853 & 33.1 & I3,4 & 25252 & 30.7 & I5.3 \\
\hline & log of paternal income & 853 & 6.435 & 0.687 & 25252 & 6.336 & I.077 \\
\hline & paternal income & & & & 25252 & II03.8 & 2203.2 \\
\hline \multirow[t]{5}{*}{ Sons } & age & 853 & 31.7 & 2.8 & & & \\
\hline & years of education & 853 & 8.4 & 4 & & & \\
\hline & occupational status - ISEI & 853 & 36.5 & I4.2 & & & \\
\hline & log of income & 853 & $6.47 \mathrm{I}$ & I.OI9 & & & \\
\hline & filial income & 853 & I031.6 & I3I0.9 & & & \\
\hline \multicolumn{8}{|c|}{ Comparing PNAD I976 with PNAD I996 } \\
\hline & & \multicolumn{3}{|c|}{ Sample of Sons PNAD 1996} & \multicolumn{3}{|c|}{ Sample of Fathers PNAD 1976} \\
\hline & & $\mathrm{N}$ & Mean & s.d. & $\mathrm{N}$ & Mean & s.d. \\
\hline \multirow[t]{5}{*}{ Fathers } & paternal age & & & & 40913 & 43.5 & 8.8 \\
\hline & years of education & I I034 & 3.2 & 4.2 & 40913 & 2.7 & 3.2 \\
\hline & $\begin{array}{l}\text { paternal occupation } \\
\text { status }\end{array}$ & I IO34 & 27.9 & I3,4 & 40913 & 29.I & I5.3 \\
\hline & log of paternal income & I I034 & 5.134 & 0.687 & 40913 & 5.098 & 0.939 \\
\hline & paternal income & & & & 40913 & 288.I & 635.1 \\
\hline \multirow[t]{5}{*}{ Sons } & age & I I034 & $3 \mathrm{I} .8$ & 2.8 & & & \\
\hline & years of education & I I034 & 7.7 & 4.4 & & & \\
\hline & occupational status - ISEI & I IO34 & 34.2 & I6.I & & & \\
\hline & log of income & I I034 & $6.68 \mathrm{I}$ & 0.988 & & & \\
\hline & filial income & I IO34 & I339.7 & I954 & & & \\
\hline \multicolumn{8}{|c|}{ Comparison of the 'household head's income from all sources' estimated using PDSD 2008 and PNAD 2007} \\
\hline & & $\mathrm{N}$ & Mean & s.d. & & & \\
\hline PDSD 2008 & income & 853 & I03I.0 & I03I.9 & & & \\
\hline PNAD 2008 & income from all sources & I7277 & I065.3 & I 433.4 & & & \\
\hline
\end{tabular}

Table 2

Descriptive statistics for income, occupation and education of fathers and sons

PNADs I976, I988 and I996 and PDSD 2008 


\section{ANALYSES}

The analyses were conducted in three parts: (I) mobility of the father's education on the son's education (a linear regression); (2) mobility of the father's income or occupation on the son's education (two linear regressions); and (3) mobility of the father's income or occupation on the son's income or occupation (two regressions). Next, I combine these analyses using a method proposed by Bloom \& Western (20I I).

\section{Paternal and filial education}

For the family i I defined the son's years of education, $e_{f i}$, as a function of the years of education attained by the father, $e_{p i}$. For the sons in one of the two analyzed cohorts, therefore, educational mobility is estimated using the following regression:

$$
e_{f i}=\Upsilon_{0}+\Upsilon_{p i} e_{f i}
$$

In this formula, educational mobility is quantified by the regression coefficient $Y_{p}$. The regressions for educational mobility in I 996 and 2008 are presented in Table 3 below. The difference in educational mobility between the two cohorts is given simply by the difference between the regression coefficients for each: $\Delta_{t}=r_{p 2008}-r_{p \text { I 996 }}$. In both age cohorts, the education attained by the sons is positively associated with the education attained by the fathers, but there was a reduction in the effect of the father's education on the son's education: in I996 the coefficient $\left(Y_{p}\right)$ was 0.7I4, while in 2008 it had fallen to 0.520 , a difference of -0.194 $\left(\Delta_{t}\right)$. The reduction in this coefficient means that educational inheritance decreased. Inversely we can affirm that educational mobility increased given that chances increased for sons with fathers possessing lower levels of education to attain higher levels. In addition, the intercept of the regressions $\left(Y_{0}\right)$ rose in value from 5.4 to $6 . \mathrm{I}$ - in other words, there was an overall increase in the educational level attained by sons given that for fathers with zero years of education, the value estimated for education was 5.4 years of education in 1996 and 6.I years in 2008. The value of the intercept is equivalent to the concept of structural mobility used in studies of class mobility. In sum, there was a clear decline in the effect of paternal education on the education of sons, on one hand, and a general rise in the educational level of these children between 1996 and 2008 , on the other. 


\begin{tabular}{|c|c|c|c|}
\hline \multicolumn{4}{|l|}{ Filial education } \\
\hline & 1996 & 2008 & $\Delta_{\mathrm{t}}$ \\
\hline Filial education & 0.714 & 0.520 & -0.194 \\
\hline s.d & 0.010 & (0.023) & -0.033 \\
\hline Intercept & 5.406 & 6.139 & 0.733 \\
\hline s.d & 0.046 & (0.204) & -0.250 \\
\hline R2 & 0.338 & 0.303 & \\
\hline $\mathrm{N}$ & I IO34 & 853 & \\
\hline
\end{tabular}

Table 3

Regression analysis for mobility: paternal education on filial education - I996 and 2008

\section{Paternal income and filial education, and paternal occupation and filial education}

In this second part of the study, I begin by comparing the economic and sociological approaches through an analysis of the effect of paternal income or occupation on the years of education completed by sons. To estimate these two types of mobility, taking the education of the sons as the end point, I used two regressions: one for the effect of the log of paternal income and the other for the effect of paternal occupational status (ISEI). Although the indicator for the father's socioeconomic conditions is different - income or occupation - it is worth remembering that paternal income was estimated from paternal occupation, which signifies that the two approaches (economic and sociological) are analogous. The equation below was estimated taking either paternal occupation or the log of paternal incomes as independent variable $\left(y_{p i}\right)$ - in other words, the coefficient $\alpha_{p}$ was estimated for both variables in two different regressions:

$$
\hat{e}_{f i}=\alpha_{o}+\alpha_{p} y_{p i} \text {. }
$$

We can observe similar patterns in the mobility between paternal income or paternal occupation and the education of the son to those presented above for education-education mobility. Table 4 shows a reduction of $20 \%\left(\left(3,995^{-}\right.\right.$ $2,198) / 3,995)$ in the effect of paternal income on the son's education and a much lower reduction, just $9.5 \%$ ((O, I4I-O, I 28)/O, I II), of the effect of paternal occupation on the son's education. This difference in the reduction of the effect, which signifies an increase in mobility, is probably an outcome of the fact that occupations are a more structural indicator that alters less over time, while income is a more fluctuating factor, changing over the life cycle in accordance with specific situations. At any rate, both results show the same upward trend in mobility. 


\begin{tabular}{|c|c|c|c|c|c|c|c|}
\hline \multicolumn{4}{|l|}{ (I) Filial education } & \multicolumn{4}{|l|}{ (2) Filial education } \\
\hline & 1996 & 2008 & $\Delta \mathrm{t}$ & & I996 & 2008 & $\Delta \mathrm{t}$ \\
\hline Paternal income & 3.995 & 3.198 & 0.796 & Paternal occup. & O.I4I & O.I 28 & 0.013 \\
\hline s.d & $0.05 \mathrm{I}$ & 0.167 & O.II7 & s.d & 0.002 & 0.010 & 0.008 \\
\hline Intercept & I 2.852 & I 2.16 I & 0.692 & Intercept & 3.752 & 4.218 & 0.467 \\
\hline s.d & 0.263 & I.II7 & 0.854 & s.d & 0.077 & $0.37 \mathrm{I}$ & 0.295 \\
\hline $\mathrm{R} 2$ & $0.36 \mathrm{I}$ & 0.310 & 0.052 & $\mathrm{R} 2$ & 0.244 & 0.187 & 0.058 \\
\hline $\mathrm{N}$ & I IO34 & 853 & & $\mathrm{~N}$ & I IO34 & 853 & \\
\hline
\end{tabular}

Table 4

Regression analysis for mobility: (I) paternal income for filial education, and (2) paternal occupation for filial education - I996 and 2008

\section{Paternal and filial income, paternal and filial occupation}

In order to model income and occupational mobility, I estimated two regressions, one for the income/income relation and the other for the occupation/ occupation relation. For each age cohort, the log of income of the son or the son's occupation (ISEI), $y_{f i}$, is defined as a linear function of the log of the paternal income or the paternal occupational status (ISEI), ypi. Hence I estimated two versions of the equation below: one for the income/income relation and the other for the occupation/occupation relation.

$$
\hat{y}_{f i}=\beta_{0}+\beta_{p} y_{p i}
$$

I also estimated these same regressions including the age of the son and the father. As the results were virtually identical, however, I decided to present the results of the simpler regressions. Some researchers have shown that this type of regression, at least in relation to income, can be influenced by the moment of the life cycle (age) when income is measured (Haider \& Solon, 2006). In the case of my own analyses, though, this did not influence the results as expected due to the analysis being limited to a narrow age band (27 to 36 years).

In the two regressions, applying the above equation for income and occupation, the parameter of interest is $\beta_{p}$. In the studies of income mobility in the economics tradition, this coefficient is called 'income elasticity,' which quantifies the mean persistence of income of parents between generations. In sociology, the coefficient $\beta_{p}$ for the association between the father's occupation and the son's occupation can be interpreted similarly, i.e. as a quantification of the mean persistence of the paternal occupation between generations. In the status attainment tradition of studies (sociology) this coefficient is seen as an effect of inherited (ascribed) characteristics, in opposition to acquired (achieved) characteristics like education and work experience. An elasticity of 
0.5 signifies that a I0\% difference in income between two families (two fathers) is associated with a $5 \%$ difference in the income of the sons. An analogous interpretation is made for the association between the father's and son's occupations. In other words, $\beta_{p}$ describes the mean inheritance of income or occupation between generations. As in the previous sections, the difference between the two cohorts is given by $\Delta_{t}=\beta_{p 2008}-\beta_{p 1996}$ representing the decrease in inheritance of income or occupation.

The estimates, presented in Table 5, point to a reduction in both income inheritance and occupation inheritance between 1996 and 2008. In other words, there was a rise in mobility among both age cohorts. Once again we can observe that the increase in mobility was higher when measured in terms of the log of income - a reduction of $4 \mathrm{I} \%$ in the effect of the father's income on the son's than in terms of occupational status - a reduction of $8 \%$ in the effect of the father's occupation on the son's. In fact, the increase in income mobility was much higher than the figure for occupational mobility. In I 996 a difference of $\mathrm{R} \$ 500$ in the income of two fathers implied a mean difference of $\mathrm{R} \$ 370$ in the income of the sons, while in 2008 the mean difference was R 2 I5. In occupational terms, the differences are slighter: in 1996, for example, a difference of 44 points in the occupational status ranking of the fathers - equivalent to the comparison between a doorman (27 points on the ISEI scale) and an accountant (7 I points on the ISEI scale) - implied a mean difference of 20 points in the occupational status of the sons. In 2008 this difference was I 8 points, indicating a small reduction in the effect of the father's occupation on the son's.

In addition, the intercepts of the regressions $\left(\beta_{0}\right)$ for income and occupation increased from 2.886 to 3.688 and from 2 I.8I 2 to 22.638 , respectively. In other words, there was a large increase in the mean income of the sons compared to paternal income among both cohorts and a less marked increase in the mean occupation of the sons between I 996 and 2008. The value of the intercept is equivalent to the concept of structural mobility used in studies of class mobility - i.e. mobility induced by structural changes. In the case of occupations, this change is expressed in the modification of the occupational structure, something that normally occurs with industrialization, which increases the number of urban jobs and reduces the number of rural jobs, for example. In the case of income, the structural change may be an increase or decrease in the population's average income. In Brazil both structural changes have occurred over the last two decades, though the increase in income has been stronger than the change in occupational structure, as shown by Neri (20II) and Pochman (20I2), respectively. The work of Carvalhaes et al. (20I4) advances on the two previous studies since it shows how the rise in income and changes in the occupational structure are jointly related to the reduction in income inequality. 
(I) Ln Filial education

\begin{tabular}{|c|c|c|c|c|c|c|c|}
\hline & I996 & 2008 & $\Delta t$ & & I996 & 2008 & $\Delta \mathrm{t}$ \\
\hline Paternal income & 0.734 & 0.433 & -0.301 & Paternal occup. & 0.456 & 0.419 & -0.036 \\
\hline s.d & 0.0I2 & 0.050 & 0.038 & s.d & 0.009 & 0.052 & 0.043 \\
\hline Intercept & 2.886 & 3.688 & 0.802 & Intercept & 2I.8I 2 & 22.693 & 0.880 \\
\hline s.d & 0.064 & 0.327 & 0.264 & s.d & 0.292 & I. 626 & I.335 \\
\hline $\mathrm{R} 2$ & 0.247 & 0.088 & -0.159 & $\mathrm{R} 2$ & 0.189 & O.I56 & -0.033 \\
\hline $\mathrm{N}$ & I IO34 & 853 & & $\mathrm{~N}$ & I IO34 & 853 & \\
\hline
\end{tabular}

Table 5

Regression analysis for mobility:

(I) paternal income for filial income- I996 and 2008

\section{COMBINING EDUCATIONAL MOBILITY WITH INCOME MOBILITY AND OCCUPATIONAL MOBILITY}

The above analyses indicate that educational mobility increased significantly, income mobility also increased considerably, and occupational mobility rose only fractionally between the older cohort (I996) and the younger (2008). How can we combine these results? The income elasticity (association of the log of paternal income with the log of the son's income) or the association between the father's and son's occupations can be broken down into two parts: (I) the association between the father's income and the son's or between the father's occupation and the son's (both) irrespective of the son's education, and (2) another component reflecting both educational mobility and the economic returns on the education attained by the sons. Hence we can break down income elasticity (income/income association) or occupational inheritance (occupation/ occupation association), both represented by $\beta_{p}$, into two parts:

$$
\beta_{p}=\beta_{p} \mid e^{+\varepsilon}
$$

The first component, $\beta_{p \mid e}$, is the 'inheritance of pure income' in the case of income mobility or 'pure occupational inheritance' in the case of occupational mobility, i.e. the regression coefficient of the log of the son's income on the log of paternal income controlling for the son's education or the regression coefficient of the son's occupational status on the father's occupational status controlling for the son's education - the regressions estimated to obtain these coefficient are displayed in Table 7 , in appendix. The second component, $\varepsilon$, is the "inheritance of mediated income" or the "mediated occupational inheritance," the 'effect' of the father's income or occupation via the son's education 
on the son's income or occupation. The inheritance of mediated income or mediated occupational inheritance is given by the formula:

$$
\varepsilon=\alpha_{p} \cdot \beta_{e \mid p}
$$

where $\alpha_{p}$ represents the effect of the father's income on the son's education or the father's education on the son's education (the regression coefficient - slope - of the son's education on the father's income or of the son's education on the father's occupation; see Table 3), and $\beta_{e \mid p}$ are the economic returns, in income or occupation, on the son's education - the regression coefficient of the son's income on the son's education controlling for the father's income, or the regression coefficient of the son's occupational status on the son's education controlling for the father's occupational status (see appendix). 'Inheritance mediated by education' is broken down both for income mobility and for occupational mobility. Taking income mobility as an example, we can say that income inheritance can increase even if educational inheritance decreases. Income inheritance, $\beta_{p}$, will grow when educational inheritance, $\alpha_{p}$, decreases if the decrease is cancelled out by the increase in the returns in income on the education attained, $\beta_{e \mid p}$, or by an increase in the inheritance of pure income, $\beta_{p}$ e (the increase in income controlling for the effect of the education attained by the son). The same logic applies to occupational mobility.

"Pure income inheritance" or "pure occupational inheritance" can be obtained with the formula:

$$
\beta_{e \mid p}=\rho_{p \mid e} \cdot \sigma_{f \mid e} / \sigma_{p \mid e}
$$

where $\rho_{p} \mid e$ is the partial correlation (square root of $\mathrm{R}^{2}$ of the regressions) between the father's and son's incomes or between the father's and son's occupations, in both cases controlling for the son's education, and where $\sigma_{f \mid e}$ and $\sigma_{p \mid e}$ are the standard deviations adjusted for education of the income or occupation distributions of sons and fathers, respectively. ${ }^{6}$ Generally speaking, a period of reduction in income inequality or variance in the occupational structure will be reflected in a reduction of the ratio spread of income or occupational status, $\sigma_{f \mid e} / \sigma_{p} \mid e$. In income terms, if inequality decreases, pure income inheritance can decrease even if the correlation between the father's income and the son's, $\rho_{p} \mid e$, does not change. The same applies to occupational status. In sum, income mobility or occupational mobility can increase even if educational mobility decreases, particularly when income or occupational status inequality is decreasing.

This type of breakdown is common in studies of income mobility (Bloom \& Western, 20I I; Bjorklund \& Jantti, 2009), but little used in studies of occupational status mobility. It is useful since it formalizes the contribution of the reduction in inequality to the increase in mobility. Changes in the distribution of income or in the distribution of occupational status are thus important to understanding the inheritance of economic advantages. In this approach, mobility is seen as the distance travelled from origin to destination. This breakdown, 
initially proposed by Bloom \& Western (20I I), is useful because it presents three types of information: elasticity (income/income) or slope of the occupation/occupation regression, correlation (income/income or occupation/occupation) and the ratio between the income distributions of fathers and sons or the ratio between the occupational status distributions of fathers and sons. In addition, I control for education, relating educational mobility to occupational status or income mobilities.

Table 6 presents the breakdowns for income and occupational mobility between income inheritance and pure occupation inheritance (discounting the effect of education) and mediated inheritance (mediated by education). A second breakdown of pure inheritance is also undertaken between two factors: one dependent on the association between the income or occupation of fathers and sons, and the other relating to the change in the degree of inequality (in either income or occupation) between the two generations. Mediated inheritance is also broken down into two factors: one for the link between the father's income or occupation and the son's education (representing educational attainment), and the other for the relation between the son's education and the son's income or occupation (representing the returns on education).

The breakdown of income elasticity indicates that $54 \%$ of the increase in mobility was due to the son's education and $46 \%$ to other factors unconnected to education. In other words, $54 \%$ of the increase was due to factors related to access to the educational system, which, as we know, has increased enormously in Brazil over recent decades; and $46 \%$ to factors related to the labor market, such as less discrimination, less difference between regional work markets, and a constant increase in the minimum wage. I also undertook a second breakdown of both 'pure income inheritance' and 'mediated income inheritance.' Pure inheritance decreased both due to a $32 \%$ fall in the direct correlation between the father's income and the son's income $\left(\rho_{p \mid e}\right)$ and due to the $31 \%$ decrease in income inequality between the paternal and filial generations $\left(\sigma_{f \mid e} / \sigma_{p \mid e}\right)$. Mediated inheritance, in turn, decreased because the association between the father's income and the son's education weakened by 20\% between I 996 and 2008 , and because the association between the son's education and the son's income decreased by I $3 \%$ during the same period.

There was also a reduction in 'occupational inheritance,' though more modest than the reduction in 'income inheritance.' While the latter decreased by $4 \mathrm{I} \%$ (from 0.734 to 0.433 ), the former dropped by just $8 \%$ (from 0.456 to $0.4 \mathrm{I}$ ). This difference is unsurprising. Income tends to change more over the course of the person's life cycle and as a consequence of more immediate structural changes in supply and demand mechanisms within the labor market. ${ }^{7}$ The occupational structure, for its part, changes more slowly, since it depends on deeper transformations in the economy's structure of production. In other words, changes in the occupational structure are necessarily slower than chang- 
es in the income structure, which implies relatively different trends in income and occupational mobilities. In any event, both types of mobility increased in the period between 1996 and 2008, a trend also encountered in terms of changes in class mobility (Ribeiro, 2012).

'Occupational inheritance' can also be broken down into 'pure' and 'mediated.' In this case, however, the pattern of changes is a little more complex. 'Pure occupational inheritance,' discounting the influence of the education attained by sons, increased between 1996 and 2008. This increase was counterbalanced by a decrease in occupational inheritance mediated by the son's education. In other words, the increase in occupational mobility was due to mechanisms involving the son's education. The analyses in this article explore two mechanisms: the first related to the access to education by sons whose fathers had a different occupational status (equalization mechanisms in access to education), and the second related to the link between educational qualifications and access to higher status jobs (mechanism of returns on education in the work market). The results of this breakdown show that the mechanism of returns on education is stronger than the equalization of access to education and, therefore, explains a larger proportion of the increase in mobility. Furthermore the results indicate that there was a fall of around $20 \%$ in the association between the father's income and the son's education, and a $38 \%$ reduction in the association between the son's education and occupational status $\left(\beta_{p} \mid e\right)$ between 1996 and 2008. The reduction in 'mediated inheritance' was counterbalanced by an increase in 'pure inheritance': this signifies that mechanisms unconnected to the educational system became more relevant to occupational mobility. For example, fathers may have been able to help their sons via their networks of social relations (social capital) or perhaps discrimination increased in the labor market, or some other kind of mechanism. These results are very similar to those already observed in terms of the trends of class mobility in Brazil (Ribeiro, 20I2; Torche \& Ribeiro, 20I0), though the increase in occupational status mobility that I present in this article is much more modest since I am comparing just two age cohorts between 27 and 36 years in 1996 and in 2008. 


\begin{tabular}{|c|c|c|c|c|}
\hline & 1996 & 2008 & $\Delta$ & $\Delta \%$ \\
\hline Income & & & & \\
\hline Breaking down $\beta_{p}$ & & & & \\
\hline Income elasticity, $\beta_{p \mid e}$ & 0.734 & 0.433 & -0.301 & IOO \\
\hline Pure income inheritance, $\beta_{p \mid e}$ & 0.245 & 0.106 & -O.I39 & 46 \\
\hline Mediated income inheritance, $\varepsilon$ & 0.489 & 0.327 & -0.162 & 54 \\
\hline Breaking down $\beta_{p}$ le & & & & \\
\hline$\rho_{p}$ & 0.663 & 0.448 & --- & --- \\
\hline$\sigma_{s \mid e} / \sigma_{p} \mid e$ & 1.005 & 0.691 & --- & --- \\
\hline Breaking down $\varepsilon$ & & & & \\
\hline$a_{p}$ & 3.995 & 3.198 & --- & --- \\
\hline$\beta_{p \mid e}$ & O.I22 & 0.106 & --- & --- \\
\hline Occupation & & & & \\
\hline Breaking down $\beta_{p}$ & & & & \\
\hline Occupational inheritance, $\beta_{p}$ & 0.456 & 0.419 & -0.036 & IOO \\
\hline Pure occupational inheritance, $\beta_{p \mid e}$ & 0.163 & 0.210 & 0.047 & -129 \\
\hline Mediated occupational inheritance, $\varepsilon$ & 0.293 & 0.210 & -0.083 & 229 \\
\hline Breaking down $\beta_{p \mid e}$ & & & & \\
\hline$\rho_{p}$ & 0.655 & 0.570 & --- & --- \\
\hline$\sigma_{\mathbf{s}} \mid \mathbf{e} / \sigma_{p \mid e}$ & I.044 & $0.94 \mathrm{I}$ & --- & --- \\
\hline Breaking down $\varepsilon$ & & & & \\
\hline$a_{p}$ & O.I4I & O.I 28 & --- & --- \\
\hline$\beta_{p \mid e}$ & 2.077 & I. 643 & --- & --- \\
\hline
\end{tabular}

Table 6

Breakdown of the changes in income mobility between age cohorts by colour or race 


\section{CONCLUSIONS AND DISCUSSION}

Intergenerational mobility is increasing in Brazil in terms of social class, occupational status, income or education. In the above analyses, however, I have shown that the increase was more pronounced for income mobility than for occupational status mobility. This difference can be explained by the fact that income is a more volatile indicator of socioeconomic conditions than occupation. As well as presenting trends in income and occupational status mobility, I analyzed the mediating effect of educational mobility and the education attained by the son with the aim of studying the mechanisms related to this increase in mobility. The analyses of occupational mobility complement previous studies on class mobility, which indicate not only an increase in mobility since the I970s, but also the same trends related to the mediating role of education. The analyses of income mobility reveal, however, a distinct role played by the adult children's education. These results show that the economic and sociological approaches should be viewed as complementary rather than as distinct alternatives to examining the same theme. In other words, the two disciplines need to combine efforts in order to broaden our understanding of processes of transmitting and overcoming inequalities.

The reduction in 'occupational inheritance' between 1996 and 2008 shows a mixed pattern. On one hand there was an increase in 'pure occupational inheritance': in other words, the direct association (discounting the effect of education) between the father's occupation and the son's occupation increased. This result indicates that factors related to the labor market and to the advantages transferred directly from fathers to sons have become more important over the period studied. Hence the sociological approach shows us that scholars of social inequalities in Brazil need to investigate in more depth mechanisms such as discrimination, social networks of advantages and forms of horizontal stratification in the education system. Put otherwise, the increase in 'pure occupational inheritance' may be both a consequence of social processes occurring within the labor market (discrimination and social networks providing advantages) and a product of the fact that sons of fathers with more occupational status may be enjoying access to better schools and universities. As the data used by myself does not differentiate between the quality of the education attained by sons, it may well be that this kind of stratification is being captured indirectly by the effects of 'pure occupational inheritance.' The sociological approach suggests that more research on these kinds of mechanisms is essential in order for us to obtain a better understanding of the process of stratification. On the other hand, the breakdown of 'mediated occupational inheritance' indicated that there was little equalization of access to education (the association between the father's occupation and son's education decreased only slightly) and a much larger decrease to educational returns in terms of the occupational status attained (the association between the son's education and 
occupational status). All these elements, however, combined to produce a fairly modest increase in occupational mobility.

The increase in income mobility between 1996 and 2008 was not only higher than the increase in occupational status mobility, it was also attained through other mechanisms. Both pure income inheritance and income inheritance mediated by education decreased over the period studied. Pure inheritance decreased for two reasons: the reduction in income inequality between generations and the reduction in the direct association between the incomes of fathers and sons. These results indicate that changes to the income structure led to a rise in mobility. Mediated income inheritance decreased mainly because there was more equality in access to education (the association between the father's income and the son's education decreased) and, at a lower level, due to the reduction in the returns in income from the education attained by sons (the association between the son's education and income). Hence studies adopting an economic perspective (income mobility) lead us to attribute a greater influence to the role played by education in the evolution of mobility.

The analyses described above show that there was an increase in social mobility irrespective of the socioeconomic indicator used (income, occupational status or education), though different mechanisms explain this increase for income and occupational status mobilities. Divergences in the patterns and trends of occupational and income mobilities are not particular to Brazil: studies in various other countries also point to this kind of inconsistency (Torche, 2015). For some time scholars of social mobility have been suggesting that these kinds of divergence should be resolved through the use of models and analyses combining occupational and income mobility (Morgan, Grusky \& Fields, 2006) and indeed studies are now being developed along these lines (Breen, Mood \& Jonsson, 2016). The limits of our knowledge in this area of studies indicates that sociological approaches must be open to economics and vice-versa. I hope that my analyses in this article can inspire other researchers to work along the same lines.

Received on 08/II/20I6 | Revised on Io/26/20I6 | Approved on I2/oI/20I6 
Carlos Antonio Costa Ribeiro holds a PhD in Sociology from Columbia University and is a professor at Institute of Social and Political Studies of the State University of Rio de Janeiro (Iesp-Uerj). His main research theme concerns the determinants of intergenerational and life-cycle inequality of economic opportunity. His books include Estrutura de classes e mobilidade social no Brasil (2007); Desigualdade de oportunidades no Brasil (2009), and Juventude, escola e trabalho (2014). 


\section{APPENDIX}
(I) Ln Filial education
(2) Filial education

\begin{tabular}{|c|c|c|c|c|c|c|c|}
\hline & I996 & 2008 & $\Delta \mathrm{t}$ & & I996 & 2008 & $\Delta \mathrm{t}$ \\
\hline Filial Edu. & O.I 22 & 0.106 & -0.016 & Filial Edu. & 2.077 & I. 643 & -0.434 \\
\hline s.d & 0.002 & 0.062 & 0.060 & s.d & 0.030 & O.I37 & 0.106 \\
\hline Paternal income & 0.245 & 0.102 & -0.143 & Paternal occup. & 0.163 & 0.210 & 0.047 \\
\hline s.d & 0.013 & 0.012 & $-0.00 I$ & s.d & 0.009 & 0.048 & 0.039 \\
\hline Intercept & 4.458 & 4.930 & $0.47 \mathrm{I}$ & Intercept & I 4.020 & I5.76I & I.74I \\
\hline s.d & 0.060 & $0.34 \mathrm{I}$ & $0.28 \mathrm{I}$ & s.d & 0.270 & I. 562 & I. 292 \\
\hline $\mathrm{R} 2$ & 0.440 & 0.201 & & $\mathrm{R} 2$ & 0.430 & 0.325 & \\
\hline $\mathrm{N}$ & I I034 & 853 & & $\mathrm{~N}$ & I IO34 & 853 & \\
\hline
\end{tabular}

Table 7

Regression analysis for mobility: (I) Income of Father and Income of Son for Income of Son, and (2) Occupation of Father and Education of Son for Occupation of Son - 1996 and 2008

\section{NOTES}

I Calculated by the author using data from the National Household Sample Survey (Pesquisa Nacional por Amostragem de Domicílios: PNAD) for 1973, 1982 and 1996, and the Social Dimensions of Inequalities Survey (Pesquisa Dimensões Sociais das Desigualdades: PDSD) 2008.

2 Ibid.

3 Details on the PNAD samples can be found at <www.ibge. gov.br>, and on the PDSD sample at <www.iesp.uerj.br>.

4 The retrospective measurement for fathers' education is not exactly in years of education, since it aggregates higher levels of education in ranges. Therefore, I used the middle point for these ranges. In fact, all educational variables are measured following this strategy.

5 In Portuguese: Instituto Brasileiro de Geografia e Estatística.

6 It is important to remember that the standard deviation for paternal income $\left(\sigma_{p \mid e}\right)$ was obtained from estimated income and is lower than the standard deviation of pa- 
ternal income observed in the PNADs for 1976 and 1988 (see Table 2). This difference could generate some degree of inconsistency. Consequently I conducted a number of sensitivity analyses using the standard deviations observed in the 1976 and I988 samples. Although the results are slightly different, all the trends and differences continue to follow the same pattern.

7 Although I use 'income from all sources' in this article, we know that more than $80 \%$ of this income is obtained in the work market. Nonetheless, other mechanisms related to family structure undoubtedly help explain the observed trend in mobility.

\section{BIBLIOGRAPHY}

Agristi, Joshua D. \& Krueger, Alan. (I992). The effect of age at school entry on educational attainment: an application of instrumental variables with moments from two samples. Journal of the American Statistical Association, 87/4I8, p. 328-336.

Becker, Gary. (1964). Human capital. New York: Columbia University Press.

Becker, Gary \& Tomes, Nigel. (I986). Human capital and the rise and fall of families. Journal of Labor Economics, 4: SI-S39.

Bills, David; Godfrey, Daramea \& Haller, Archibald. (1985). A scale to measure the socioeconomic status of occupations in Brazil. Rural Sociology, 50, summer, p. 225-250.

Bills, David \& Haller, Archibald. (1985). Socioeconomic development and social stratification: reassessing the Brazilian case. Journal of Developing Areas, I9, p. 59-69.

Bjorklund, Anders \& Jäntti, Markus. (2009). Intergenerational income mobility and the role of family background. In: Bowles, Samuel; Gintis, Herbert \& Groves, Melissa Osborne (eds.). Unequal chances. New York: Russel Sage Foundation, p. I45-I64.

Bjorklund, Anders \& Jäntti, Markus. (1997). "Intergenerational income mobility in Sweden compared to the United States." American Economic Review, 87/5. p. Ioo9-IoI8.

Blau, Peter \& Duncan, Otis. (1967). The American occupational structure. Nova York: Wiley. 
Bloom, Deirdre \& Western, Bruce. (20II). Cohort change and racial differences in educational and income mobility. Social Forces, 90/2, p. 375-395.

Bourdieu, Pierre \& Passeron, Jean-Claude. (1977). Reproduction in education, society and culture. London/Beverly Hills: Sage.

Bourguignon, François; Ferreira, Francisco \& Menéndez, Marta. (2007). Inequality of opportunity in Brazil. Review of Income and Wealth, 53/4, p. 585-618.

Breen, Richard (ed.). (2005). Social mobility in Europe. Oxford: Oxford University Press.

Breen, Richard \& Jonsson, Jan. (2005). Inequality of opportunity in comparative perspective: recent research on educational attainment and social mobility. Annual Review of Sociology, 3I, p. 223-243.

Breen, Richard; Mood, Carina \& Jonsson, Jan. (2016). How much scope for a mobility paradox? The relationship between social and income mobility in Sweden. Sociological Science, 4 .

Carvalhaes, Flávio et al. (20I4). Os impactos da geração de empregos sobre as desigualdades de renda: uma análise da década de 2000. Revista Brasileira de Ciências Sociais, 29/85, p. 79-98.

Corack, Miles (ed.). (2004). Generational income mobility in North America and Europe. Cambridge: Cambridge University Press.

Dunn, Christopher. (2004). The intergenerational transmission of earnings: evidence from Brazil. PhD Thesis. Departament of Economics, University of Michigan.

Erickson, Robert \& Goldthorpe, John. (1993). The constant flux: a study of class mobility in industrial societies. Oxford: Clarendon Press.

Ferreira, Sergio \& Veloso, Fernando. (2006). Intergenerational mobility of wages in Brazil. Brazilian Review of Econometrics, 26/2, p. I8I-2II.

Gazenboom, Harry; Treiman, Donald \& De Graff, Paul. (I993). A standard international socio-economic index of occupational status. Social Science Research, 2I, p. I-56. 
Goldberger, Arthur. (1989). Economic and mechanical models of intergenerational transmission. The American Economic Review, 79/3, p. 504-513.

Haider, Steven \& Solon, Gary. (2006). Life-cycle variation in the association between current and lifetime earnings. American Economic Review, 96/4, p. I308-1320.

Haller, Archibald. (I99I). Ascription and status transmission in Brazil. In: Scoville, James (ed.). Status influence in third world labor markets: caste, gender and custom. Berlin: De Gruyter Inc., p. 63-93.

Hauser, Robert \& Logan, John Allen. (I992). How to mesasure intergenerational occupational persistence. American Journal of Sociology, 97, p. I689-I7I I.

Hauser, Robert \& Warren, John Robert. (I997). Socioeconomic indexes for occupations: a review, update, and critique. Sociological Methodology, 27/I, p. 177-298.

Hout, Michael. (20I5). A summary of what we know about social mobiliy. The Annals of the American Academy of Political and Social Sciences, 657.

Hout, Michael \& Diprete, Thomas. (2006). What we have learned: RC28's contributions to knowledge about social stratification. Research in Social Stratification and Mobility, 24/I, p. I-20.

Morgan, Stephen; Grusky, David \& Fields, Gary. (2006). Mobility and inequality: frontiers of research in Sociology and Economics. Palo Alto: Stanford University Press.

Neri, Marcelo. (20II). A nova classe média: o lado brilhante da base da pirâmide. Rio de Janeiro: Editora Saraiva.

Osório, Rafael. (2009). Desigualdade racial de renda no Brasil: 1976-2006. Tese de doutorado. Programa de Pós-Graduação em Sociologia, Universidade de Brasília, Brasília.

Pastore, Jose. (I98I). Inequality and social mobility in Brazil. Madison: University of Wisconsin Press.

Pastore, Jose \& Silva, Nelson do Valle. (2000). Mobilidade social no Brasil. São Paulo: Markon.

Pero, Valéria \& Szerman, Dimitri. (2008). Mobilidade intergeracional de renda no Brasil. Pesquisa e Planejamento Econômico, 38/I, p. I-35. 
Pochman, Marcio. (2012). Nova classe média? o trabalho na base da pirâmide social brasileira. São Paulo: Boitempo.

Ribeiro, Carlos Antonio Costa. (2012). Quarenta anos de mobilidade social no Brasil. Dados, 55/3, p. 64I-679.

Ribeiro, Carlos Antonio Costa. (2007). Estrutura de classe e mobilidade social no Brasil. Bauru: Edusc.

Scalon, Celi. (1999). Mobilidade social no Brasil: padrões e tendências. Rio de Janeiro: Revan/Iuperj/Ucam.

Solon, Gary. (2004). A model of intergenerational mobility variation over time and place. In: Corack, Miles (ed.). Generational income mobility in North America and Europe. Cambridge: Cambridge University Press, p. 38-47.

Torche, Florencia. (2015). Analysis of intergenerational mobility an interdisciplinary review. The Annals of the American Academy of Political and Social Sciences, 657, p. 37-62.

Torche, Florencia \& Ribeiro, Carlos Antonio Costa. (2010). Pathways of change in social mobility: industrialization, education and growing fluidity in Brazil. Research in Social Stratification and Mobility, 28/3, p. 29I-307. 
Palavras-chave

Desigualade de renda; mobilidade intergeracional; mobilidade de renda; mobilidade de ocupação; mobilidade de educação.

Keywords

Income inequality; intergenerational mobility; income mobility; occupational mobility; educational mobility.
MOBILIDADE INTERGERACIONAL OCUPACIONAL E DE RENDA NO BRASIL ENTRE AS DÉCADAS DE 1990 E 2000

\section{Resumo}

Este artigo apresenta as tendências históricas da mobilidade intergeracional de renda no Brasil entre as décadas de I 990 e 2000 a partir da análise de duas coortes de idade. Os resultados indicam um aumento significativo da mobilidade social. Um segundo objetivo é comparar as perspectivas da economia e da sociologia sobre mobilidade intergeracional, utilizando para tanto as tendências das mobilidades de renda e de status ocupacional. Enquanto a primeira aumentou bastante, a segunda aumentou de forma bem mais modesta. Finalmente, analisa a relação entre mobilidade intergeracional de educação e os dois outros tipos de mobilidade. Ao decompor as mobilidades de renda e de ocupação em fatores que ligam diretamente pais a filhos (herança pura) e fatores mediados pela educação (herança mediada), revelam-se resultados significativamente diferentes para renda e para ocupação.

\section{INTERGENERATIONAL OCCUPATIONAL AND INCOME MOBILITY IN BRAZIL BETWEEN THE 1990s AND 2000s}

\section{Abstract}

This article presents the historical trends in intergenerational income mobility in Brazil between the Ig9os and 2000s, based on an analysis of two age cohorts. The findings indicate a significant increase in social mobility. A second objective is to compare economic and sociological approaches to intergenerational mobility, utilizing trends in income mobility and occupational status mobility for this purpose. While the former rose substantially, the latter increased much more modestly. Finally, the article analyses the relation between intergenerational mobility in education and the other two types of mobility. Breaking down income and occupational mobilities into those factors that directly link parents to children (pure inheritance) and other factors mediated by education (mediated inheritance) reveals significantly different results for income and occupation. 